Our findings are in direct contrast with those of Dundee et al. ${ }^{2}$ A much larger study, of more than 200 subjects, would be required to rule out even a minor antiemetic effect of acupuncture (that is, a $10 \%$ difference between the groups). We chose, however, to limit our study to 46 subjects, as our results suggested that acupuncture at the P6 locus, in the way that we used it, is unlikely to be a clinically useful prophylactic for postoperative nausea and vomiting.

1 Churchill-Davidson HC. A practice of anaesthesia. London: Butterworths;1986:950-3.

2 Dundee JW, Chestnutt WN, Gahaly RG, Lynas AGA. Traditional Chinese acupuncture: a potentially useful antiemetic? $\mathrm{BrMed}$ f 1986;293:583-4.

3 Palazzo MGA, Strunin L. Anaesthesia and emesis. I. Etiology. Can Anaesth Soc $f$ 1984;31:178-87.

4 Vincent CA, Richardson PH. The evaluation of therapeutic acupuncture: concepts and methods. Pain 1986;24:1-13.

5 Tseng CK, Tay AAL, Pace NL, Westenskow DR, Wong KC. Electro-acupuncture modification of halothane anaesthesia in the dog. Can Anaesth Soc $\mathcal{F}$ 1981;28:125-8.

(Accepted 26 August 1987)

Dunedin Public Hospital, New Zealand

W M WEIGHTMAN, MB, DA, anaesthetic registrar

Southland Hospital, New Zealand

M ZACHARIAS, FFARCS, PHD, consultant anaesthetist

Department of Preventative and Social Medicine, University of Otago

P HERBISON, MSC, biostatistician

Correspondence to: Dr M Zacharias, Southland Hospital, Invercargill, New Zealand.

\section{Facial flushing after intra-articular injection of steroid}

Several systemic side effects of intra-articular injection of steroid have been described. ${ }^{1-5}$ One of these is flushing, an unpleasant subjective sensation of warmth with erythema that affects the face and upper trunk. Whether it depends on sex, age, or disease has not been determined. Although it is generally considered to be a trivial complication ${ }^{5}$ and has a reported frequency of less than $1 \%,{ }^{1}$ spontaneous complaints of flushing after injection of steroid from several patients led us to reassess the frequency and clinical importance of this reaction in a prospective study.

\section{Patients, methods, and results}

We studied 130 consecutive patients attending this unit who required intraarticular steroid injection of one knee. Before injection they were specifically questioned about vasomotor instability (perimenopausal flushing, flushing with alcohol, and easy blushing). Each knee was aspirated "to dryness" by a superolateral approach, and $40 \mathrm{mg}$ triamcinolone acetonide was then injected under low resistance. The occurrence of nine possible adverse reactions, including flushing, in the seven days after injection was determined with a questionnaire provided at the time of the injection. Patients were not told that flushing was the primary interest. Between four and six weeks later they were seen again to clarify and confirm their answers. Patients who reported flushing and subsequently needed further intra-articular treatment of the same knee were injected with either triamcinolone acetonide $40 \mathrm{mg}$ or triamcinolone hexacetonide $20 \mathrm{mg}$. Subsequent adverse reactions were assessed as before. Statistical comparison between the groups was made with the $\chi^{2}$ test with Yates's continuity correction.

Assessment of reactions was not possible for 26 patients who lost or failed to complete the questionnaire or who gave inconsistent reports and for four others who responded positively to every question. All 30 were excluded from the

Details of patients studied

\begin{tabular}{lccc}
\hline & $\begin{array}{c}\text { Patients who } \\
\text { flushed }(\mathrm{n}=40)\end{array}$ & $\begin{array}{c}\text { Patients who did } \\
\text { not flush }(\mathrm{n}=60)\end{array}$ & $\begin{array}{c}\text { Total } \\
(\mathrm{n}=100)\end{array}$ \\
\hline $\begin{array}{l}\text { Mean (SEM) age in years and } \\
\text { range }\end{array}$ & $66(1 \cdot 7)$ & $63(1 \cdot 7)$ & $64(1 \cdot 2)$ \\
$\begin{array}{l}\text { Ratio of men: women } \\
\text { No(\%) of patients with: }\end{array}$ & $35-82$ & $32-88$ & $32-88$ \\
Rheumatoid arthritis & $1: 3 \cdot 4$ & $1: 1$ & $1: 2 \cdot 2$ \\
$\begin{array}{l}\text { Osteoarthritis } \\
\text { Pyrophosphate arthropathy }\end{array}$ & $13(33)$ & $23(38)$ & $36(36)$ \\
No(\%) with previous motor instability & $11(28)$ & $18(30)$ & $29(29)$ \\
& $6(15)^{\star}$ & $19(32)$ & $35(35)$ \\
\end{tabular}

^All women. analysis. The table shows the results for the remaining 100 patients, who had rheumatoid arthritis (36 patients), osteoarthritis (29), or pyrophosphate arthropathy (35). Flushing occurred in $\mathbf{4 0}$ and was serious in 15 . It occurred at a mean interval of 19 (SEM 1.7; range 2-30) hours after injection and lasted for a mean of 36 (SEM 4; range 6-96) hours. It was associated with being female $\left(\chi^{2}=7 \cdot 9\right.$, $\mathrm{p}<0.01$ ) but not with diagnostic category (rheumatoid arthritis $\chi^{2}=0.65, \mathrm{p}>0.45$; osteoarthritis $\chi^{2}=0.24, \mathrm{p}>0.45$; pyrophosphate arthropathy $\chi^{2}=0.41, \mathrm{p}>0.45$ ), previous vasomotor instability $\left(\chi^{2}=0 \cdot 19, p>0 \cdot 45\right)$, or age.

Twenty four patients who flushed needed a repeat injection in the same knee. All six who received triamcinolone acetonide reported flushing, whereas only nine of the 18 who received triamcinolone hexacetonide developed the reaction, which was reported to be less severe than before in all cases.

\section{Comment}

Flushing was a common side effect of intra-articular steroid treatment, occurring in $40 \%$ of the documented patients (31\% of the initial study group) and being unpleasant in $15 \%$ ( $12 \%$ of the initial group). The reaction was significantly more common in women $(p<0.01)$ but seemed independent of age, disease category, or prior vasomotor instability. Previous underestimation of the frequency and severity of this response, particularly in women, is difficult to explain. Although in this study the patients were specifically questioned about nine side effects after the injection, the proportion who gave multiple positive responses was low. No other side effect was reported by as many as $\mathbf{4 0}$ patients, and the incidence of flushing was still high when all patients in the study were included $(44 / 130 ; 34 \%)$. Every precaution was taken to ensure intra-articular rather than periarticular injection.

Flushing was reproducible within the small group of patients who were given a repeat injection of triamcinolone acetonide. Although not specifically designed to compare the frequency of side effects between different long acting steroids, the study suggested that the propensity to cause flushing may vary between different preparations. Whether the steroid, the side chain, or the vector is responsible for the flushing remains to be determined.

We thank the Arthritis and Rheumatism Council for financial support.

1 Gray RG, Gottlieb NL. Intra-articular corticosteroids. An updated assessment. Clin Orthop 1983;177:235-63.

2 Ward LE, Mason HL. Systemic effects from hydrocortisone acetate administered intra-articularly to rhejumatoid patients. $\Im$ Lab Clin Med 1953;42:961-2.

3 Koehler BE, Urowitz MB, Killinger DW. The systemic effects of intra-articular corticosteroids. f Rheumatol 1974;1:117-25.

4 Shuster S, Williams IA. Adrenal suppression due to intra-articular corticosteroid therapy. Lancet 1961;ii:171-2.

5 Gottlieb NL, Riskin WG. Complications of local corticosteroid injections. JAMA 1980;243: $1547-8$.

(Accepted 26 August 1987)

Rheumatology Unit, City Hospital, Nottingham NG5 1PB

M PATTRICK, MB, MRCP, clinical research fellow in rheumatology M DOHERTY, MA, MRCP, consultant senior lecturer in rheumatology

Correspondence to: Dr Pattrick.

\section{Tropical spastic paraparesis associated with human $\mathbf{T}$ lymphotropic virus type $I$ in an east African naturalised in Sweden}

A slowly progressive myelopathy affecting the pyramidal tracts and to a minor extent other systems is known as tropical spastic paraparesis because of a characteristic geographical distribution. ${ }^{1}$ Recent evidence suggests an aetiological role for the human T lymphotropic virus type I (HTLV-I) in this condition. ${ }^{12}$ Though HTLV-I is widespread in Africa, tropical spastic paraparesis associated with this virus has been found in only one African patient, living in the Ivory Coast (west Africa) ${ }^{3}$ We report a long record of antibodies to HTLV-I in an east African with tropical spastic paraparesis who had been resident in Sweden for 12 years.

\section{Case report}

A 31 year old Ethiopian had settled in Sweden in 1975. From the age of 16 he had had frequency and urgency of micturition and from the age of 21 he had 